\title{
CONTINENTAL BIODIVERSITY OF SOUTH AMERICAN OLIGOCHAETES: THE IMPORTANCE OF INVENTORIES
}

\author{
Martin Lindsey ChristofFersen \\ Universidade Federal da Paraíba, Departamento de Sistemática e Ecologia, 58.059-900, João Pessoa, \\ Paraíba, Brasil. E-mail: mlchrist@dse.ufpb.br
}

Christoffersen, M. L. 2010. Continental biodiversity of South American oligochaetes: The importance of inventories. Acta Zoológica Mexicana (n.s.), Número Especial 2: 35-46.

ABSTRACT. A reevaluation of South American oligochaetes produced 871 known species. Megadrile earthworms have rates of endemism around 90\% in South America, while Enchytraeidae have less than $75 \%$ endemism, and aquatic oligochaetes have less than $40 \%$ endemic taxa in South America. Glossoscolecid species number 429 species in South America alone, a full two-thirds of the known megadrile earthworms. More than half of the South American taxa of Oligochaeta (424) occur in Brazil, being followed by Argentina (208 taxa), Ecuador (163 taxa), and Colombia (142 taxa). Present diversity counts of Oligochaeta are still substantially underscored. Surveys of Enchytraeidae in native forests in São Paulo 30 years ago produced a 100\% yield of new species, while this group is still unregistered in the whole northeast region of Brazil. There is clearly much basic research to be done on oligochaetes in South America.

Key words: Faunistics, inventory, megadriles, microdriles, neotropics.

Christoffersen, M. L. 2010. La biodiversidad continental de los oligoquetos en Sudamérica: la importancia de los inventarios. Acta Zoológica Mexicana (n.s.), Número Especial 2: 35-46.

RESUMEN. Una nueva evaluación de los oligoquetos sudamericanos tuvo como resultado 871 especies. Lombrices megadriles tienen un endemismo de alrededor de 90\%, en cuanto Enchytraeidae tiene menos de $75 \%$ de endemismo, y los microdilos acuáticos tienen menos de $40 \%$ de los taxa endémicos en América del Sur. Los Glossoscolecídeos representan 429 especies solamente en América del Sul, constituyendo dos tercios de los megadriles conocidos en este continente. Más de la mitad de los taxa sudamericanos de Oligochaeta (424) se encuentran en el Brasil, seguido de la Argentina (292 taxa), Ecuador (163 taxa), y Colombia (142 taxa). Cómputos actuales de los oligoquetos son todavía significativamente subestimados. Los muestreos de Enchytraeidae en los bosques nativos de San Pablo realizados hace 30 años resultaron en $100 \%$ de especies endémicas. En cuanto este grupo todavía no fue muestreado en toda la región Nordeste del Brasil. Es claro que falta mucha investigación básica por hacer en lo que se refiere a los Oligoquetos de América del Sur.

Palabras clave: Fauna, inventario, megadrilos, microdrilos, región Neotropical.

Recibido: 16/05/2008; aceptado: 08/01/2010. 


\section{INTRODUCTION}

Species richness is a fundamental component of biodiversity. Most of the biodiversity on earth, estimated to be anywhere from 3.5 to 10.5 million species (Alroy 2002), is due to invertebrates, many of them soil-inhabiting (Decaëns et al. 2006).

South American invertebrates receive much less attention in faunistic inventories than vertebrates, plants and human-associated insects. Furthermore, aquatic and terrestrial oligochaetes, that represent over 10,000 species worldwide, are poorly represented in South America in available internet initiatives (ITIS, Diversity of Life, Global Biodiversity Information Facility, etc.).

In recent years, the importance of oligochaetes for ecology, applications in agriculture, usefulness to humans, and awareness of species numbers, is increasing worldwide, but their true diversity in the megadiverse South American continent is sorely underscored.

Fragoso \& Brown (2007) compiled all terrestrial megadriles recorded for Latin America for the first time, $93 \%$ of which were native. Previous faunal lists existed only for Argentina, Chile, Brazil, Ecuador, Colombia, the Caribbean Islands, Central America, and Mexico.

There is now strong morphological evidence that Enchytraeidae represent the sister group of the megadrile earthworms (Christoffersen 2009). I thus place this family alongside the megadrile earthworms, rather than within the aquatic oligochaetes, referring to them as microdrile earthworms. Unfortunately, molecular data still place enchytraeids together with aquatic worms (Jamieson et al. 2002).

Christoffersen (2007c) has now produced the first update of aquatic microdrile oligochaetes of South America since the works of Gavrilov $(1979,1981)$ and Brinkhurst \& Marchese (1989).

\section{History of oligochaete studies in South America}

The first species of earthworms from Tropical America were discovered during the expeditions of naturalists to the new world. The first descriptions of this material were by Leuckart $(1835,1836)$. Fritz Müller (1857) described Pontoscolex corethrurus from Santa Catarina, Brazil, and Kinberg (1867) described Amynthas gracilis from the Botanical Garden of Rio de Janeiro, Brazil.

Towards the end of the nineteenth and beginning of the twentieth century, several researchers described species from South America: Franz Vejdovský, Hermann Ude, Wilhelm Michaelsen, Daniele Rosa, Gustav Eisén, Luigi Cognetti, Leo Černosvitov, Frank Evers Beddard, and William Blaxland Benham.

During the second phase of annelid studies, towards the middle of the century, the Uruguayan Ergasto Cordero, and the Germans living in Brazil Ernst Marcus and Eveline Du-Bois Reymond Marcus, became the first specialists to study South American oligochaetes. 
In the second half of the twentieth century, Per-Olof Ljungström and Catalina C. Mischis in Argentina, Gilberto Righi in Brazil, and András Zicsi, from Hungary, conducted intensive collecting expeditions in other South American countries, being responsible for the main descriptive works now available on oligochaetes from South America.

\section{MATERIAL AND METHODS}

The present review synthesizes oligochaete diversity from the literature at the regional and continental scale, focusing on the aquatic microdriles (Christoffersen 2007c), terrestrial microdriles (Enchytraeidae) (Christoffersen 2009), and megadrile earthworms (Fragoso \& Brown 2007, Christoffersen 2007a, b, 2008a, b, c, d).

\section{RESULTS}

On the basis of the most recent information available, there are now 871 known species and subspecies of Oligochaeta from South America. Two-thirds of the megadrile earthworms occurring in South America correspond to glossoscolecids (429 taxa) (Table I).

More than half of the South American taxa of Oligochaeta (424) occur in Brazil, being followed by Argentina (208 taxa), Ecuador (163 taxa), and Colombia (142 taxa) (Table II).

\section{DISCUSSION}

While values of $93 \%$ and $85 \%$ native species were registered for megadrile earthworms in Latin America and Brazil, respectively (Fragoso \& Brown 2007, Brown \& James 2007), these values are reduced to $74 \%$ and $38.5 \%$, for Enchytraeidae and aquatic microdriles of South America, respectively (Christoffersen 2007c, 2009).

In environments influenced by man, exotic species of oligochaetes, such as the earthworms $P$. corethrurus and A. gracilis usually predominate (Brown et al. 2006). Native species tend to be found preferably in well-preserved native vegetation. For instance, Christoffersen (1977, 1979a,b) explored native Atlantic forests in the State of São Paulo, finding new species only in environments not affected by human presence.

In Brazil there are approximately 750 collection sites for megadriles, but only 18 of these are from the northeast region of Brazil, with only 30 species of earthworms (James \& Brown 2006). Northeastern Brazil is particularly under-represented, even in basic inventories. Only three species of Rhinodrilus were registered in all the Caatinga Formation (Brown \& James 2007), and Enchytraeidae have still not been officially recorded from the NE of Brazil. The apparent absence of terrestrial and aquatic records within the arid region may be real in the interior arid region due to the inhos- 
Christoffersen: Continental biodiversity of South American oligochaetes

Table 1. Number of species of aquatic, microdrile and megadrile oligochaetes in South America, and their respective published inventories.

\begin{tabular}{|c|c|c|}
\hline Oligochaete group & Number of species & Reference \\
\hline Aquatic oligochaetes (Total) & 171 & \\
\hline Alluroidea & 4 & (Christoffersen 2007c) \\
\hline Capilloventridae & 1 & (Christoffersen 2007c) \\
\hline Haplotaxidae & 5 & (Christoffersen 2007c) \\
\hline Naididae & 152 & (Christoffersen 2007c) \\
\hline Narapidae & 1 & (Christoffersen 2007c) \\
\hline Opistocystidae & 3 & (Christoffersen 2007c) \\
\hline Phreodrilidae & 4 & (Christoffersen 2007c) \\
\hline Tiguassuidae & 1 & (Christoffersen 2007c) \\
\hline Microdrile earthworms (Total) & 62 & (Christoffersen 2007c) \\
\hline Enchytraeidae & 62 & (Christoffersen 2009) \\
\hline Megadrile earthworms (Total) & 638 & (Christoffersen 2007c) \\
\hline Acanthodrilidae & 66 & (Fragoso \& Brown 2007) \\
\hline Almidae & 6 & (Christoffersen 2008b) \\
\hline Criodrilidae & 1 & (Christoffersen 2008b) \\
\hline Eudrilidae & 2 & (Fragoso \& Brown 2007) \\
\hline Glossoscolecidae & 429 & (Fragoso \& Brown 2007) \\
\hline Lumbricidae & 26 & (Fragoso \& Brown 2007) \\
\hline Megascolecidae & 16 & (Fragoso \& Brown 2007) \\
\hline Ocnerodrilidae & 70 & (Christoffersen 2008a) \\
\hline Octochaetidae & 21 & (Fragoso \& Brown 2007) \\
\hline Tumakidae & 1 & (Christoffersen 2008b) \\
\hline TOTAL & 871 & \\
\hline
\end{tabular}

pitable conditions and to the temporary nature of most water courses during most of the year, unfavorable for the establishment of permanent populations of oligochaetes. Nevertheless, earthworms may occur at locations with $<100 \mathrm{~mm}$ annual rainfall (in 
India and the Negev desert, for example). As the driest sites in the NE of Brazil only rarely or very locally are below $400 \mathrm{~mm}$, native oligochaetes may still be discovered here, particularly if earthworms have had enough time to adapt to droughts that occurred in the climate of that region since the last ice-age, over the last 12,000 years.

There are other extensive regions of Brazil with almost no collections of earthworms, such as the region from south of Pará to the north of Mato Grosso (James \& Brown, this issue). The Pantanal region of central Brazil represents another underexplored area, with a total of only 11 species of earthworms (Brown \& James 2007).

In fact, there are few regional inventories of earthworms in Brazil: 18 species were reported for the state of Rio Grande do Sul (Knäpper 1972, 1977); Mato Grosso and Rondônia have 45 species (Righi 1990); the Manaus region, 40 species (Ayres \& Guerra 1981); Paraná, 55 species (Brown et al. 2004); and São Paulo State, 77 species (Brown \& James 2007).

Megadrile earthworm species biodiversity estimates have been made for all Latin American countries (Fragoso \& Brown 2007), ranging from 305 species in Brazil to 4 species in Nicaragua. However, vast areas of many countries remain unexplored. Peru, for instance, has a relatively large area, most of which still remains unknown in terms of earthworms.

The concept of Von Humboldt that species diversity declines with increasing latitude, is considered to be one of the oldest concepts in ecology (Hawkins 2001, De Deyn \& Van der Putten 2005). The geographic hypothesis assumes that tropical zones support most species because they comprise large contiguous areas, whereas extra-tropical zones are disjunct (Willig \& Bloch 2006). Diversity patterns of belowground animals have been poorly studied (Maraun et al. 2007). Yet, there are several indications that species richness is not highest in tropical regions for soil animal taxa, such as nematodes (Procter 1984), earthworms (Judas 1988, Lavelle et al. 1995) and oribatid mites (Maraun et al. 2007). However, observed richness and survey effort are highly correlated (Hortal et al. 2007).

Most biodiversity databases, including the present oligochaete compilations, lack exhaustiveness and proper geographical (environmental) coverage. Thus, the relative importance of two alternative explanatory aspects of species richness - intensity of study and elevated relative species richness in the tropics - is difficult to assess. Biological exploration still has incomparable intellectual and scientific rewards, as well as the potential to identify new biological resources and to improve our ability to manage the Earth's resources (Wheeler 1995).

Although the biggest country (Brazil) has the largest biodiversity, the correlation between area and biodiversity was not significant for the remaining countries in Latin America, when Brazil was removed (Fragoso \& Brown 2007). This puts into question whether the significantly larger number of Brazilian species is not a mere byproduct of the larger taxonomic effort of the specialist Gilberto Righi, who described more 
Christoffersen: Continental biodiversity of South American oligochaetes

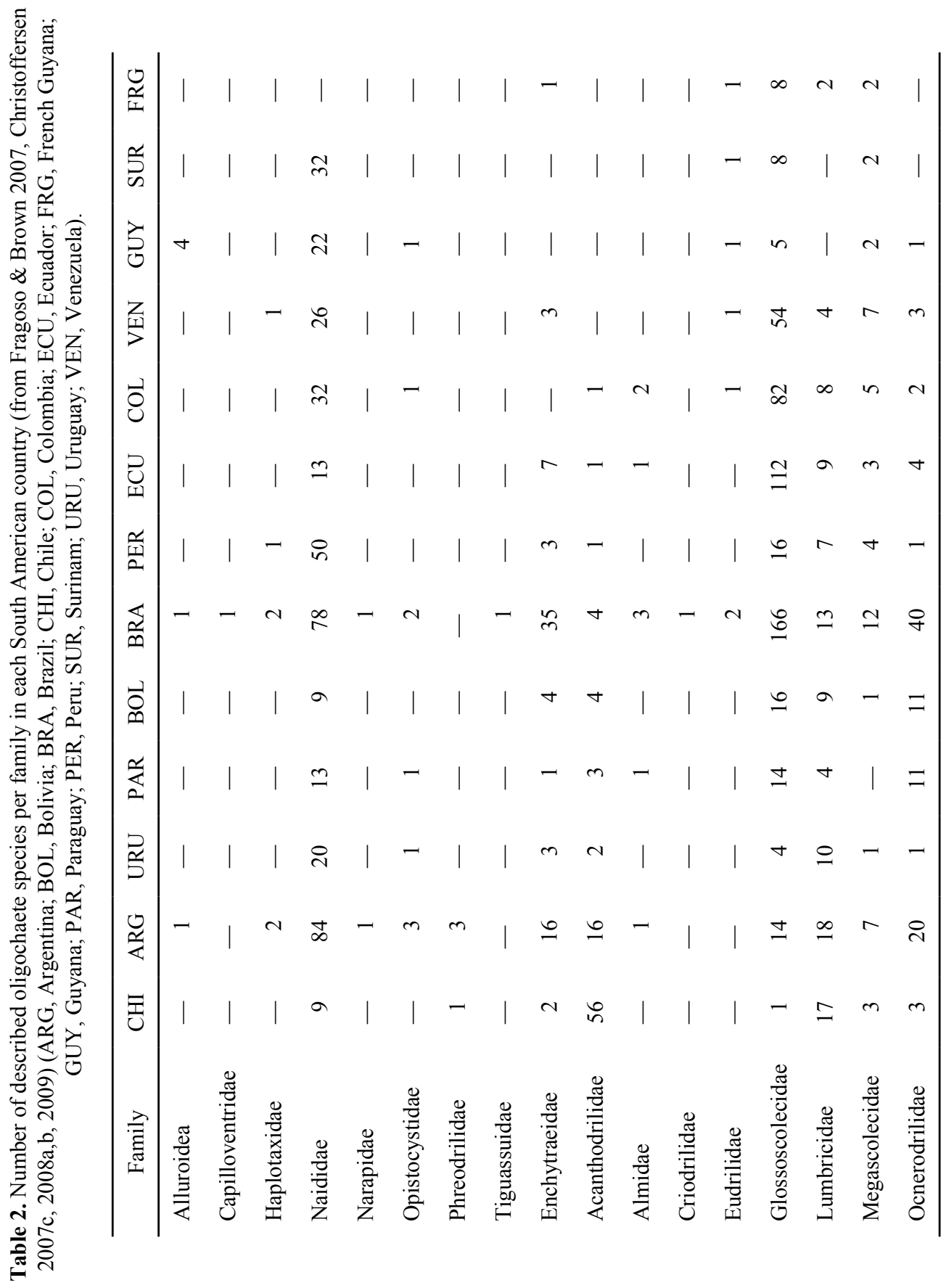




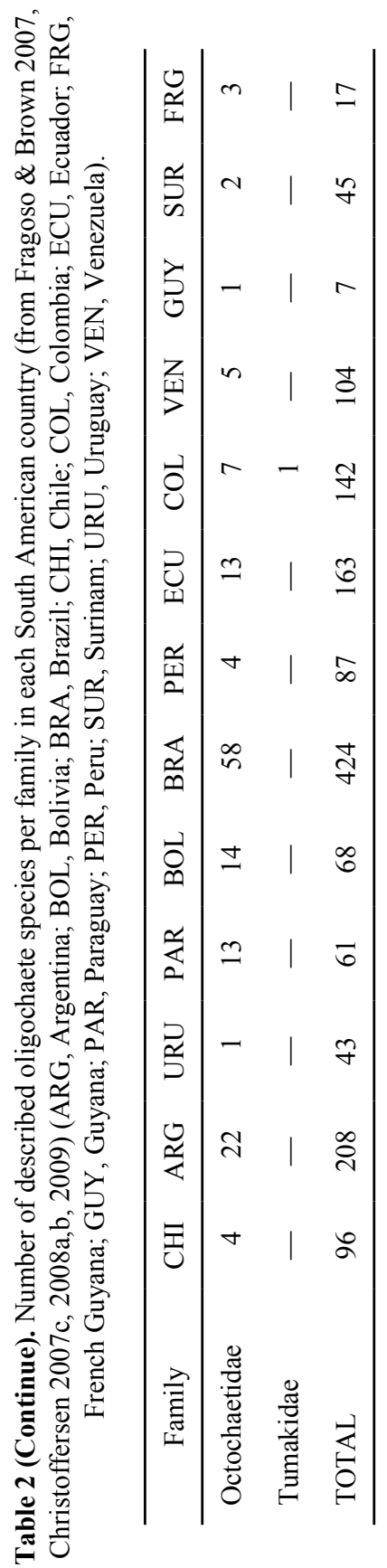


than 220 new species along more than 30 years, or about 6.4 species per year, on average (Fragoso et al. 2003).

The catalogued oligochaetes represent only a fraction of their true diversity in South America and Latin America. Therefore, our knowledge regarding oligochaetes is still in a pioneer phase. Nevertheless, the information for tropical South America appears to be better than for other tropical regions in the world. For many tropical regions, there are simply no lists of known species. For many countries, myriads of scattered records have accumulated over the centuries, with extensive synonymies (Blakemore 2002), making taxonomic research extremely time consuming.

The elaboration and publication of checklists and catalogues requires considerable effort and courage, because these works are never complete and generally include many errors. Yet, together with monographs, checklists and catalogues represent crucial databases to facilitate efficient future research.

Presently, the available catalogues for South American oligochaetes and of the adjacent northern Neotropical region are preliminary in several aspects. First of all, many more records will inevitably be added to these inventories. Next, misidentifications, synonyms and incorrect generic designations must be corrected according to the latest available taxonomic revisions. Finally, several identifications, especially in works of an ecological nature, will never be checked for lack of reference specimens deposited in biological collections. Thus, intensive field work in the tropics, organization of representative collections, good descriptions of new material, and more informative illustrations should be implemented to complete the data available from the past.

Our knowledge on the diversity of oligochaetes in South America can only be understood in a historical context. The fragmentary knowledge on oligochaetes and the lack of knowledge regarding the existing data are mainly due to the fact that specialists from European countries worked in South America for short periods of time and travelled to easily accessible areas. They took specimens to their home countries and published the results in foreign languages in periodicals generally inaccessible to South Americans. An exception was the Brazilian Gilberto Righi, who preferred to publish in Portuguese and in local journals.

New records are usually only published in considerable numbers by specialists of certain groups. During faunistic surveys, some groups are overly represented and others are under-represented or neglected. Gilberto Righi concentrated efforts on the Brazilian megadriles, and András Zicsi emphasized Andean megadriles from Chile and Ecuador. Microdrile earthworms (except for the punctual efforts by Righi 1973, 1974a,b, 1975, 1978, 1981a, b, 1988, Bittencourt 1974, Christoffersen 1976, 1977, 1979a, b, Dozsa-Farkas 1989, Römbke \& Hanagarth 1994, Römbke et al. 1999, Schmelz \& Collado 2005, Schmelz \& Römbke 2005) have not been subjected to systematic sampling. 


\section{FUTURE PERSPECTIVES}

Hopefully, the present catalogues will inspire colleagues and students to deepen our understanding of South American oligochaetes. It is also hoped that pioneering efforts will be attempted for other great and little known tropical regions (e.g., Africa and Asia).

Catalogues are useful for a wide range of activities (Stork \& Samways 1995). The data summarized in the present paper provides the first overview of the known diversity of South American enchytraeids and megadrile earthworms, and the most recent overview in the case of the aquatic oligochaetes. These recent inventories facilitate access to data scattered in numerous small publications and books, providing a starting point for future taxonomic research on oligochaetes of South America. This includes references to literature containing tools for identification and methods on faunistic sampling.

A more complete checklist should strive to include more information necessary for the sustainable management of natural resources: relative data on endemism, local diversity hotspots, biological invasions, and other patterns of biodiversity. Such enhanced knowledge can allow observations of changes of biodiversity over time, the identification of recently introduced oligochaetes, and the loss of endemic diversity.

Progress in oligochaete studies in South America should include not only new records and new species, but also ecological data based on long-term observations, discovery of interactions and associations of oligochaetes with other organisms. There is also need for phylogenetic studies based on morphology and molecules (see Siqueira et al., this issue), and for the construction of a phylogenetic system for clitellates. Their origin and relationships to other marine annelid groups are still far from being resolved with molecular methods and need broad, insightful, intergroup research above the normal domains of systematic specialists. These efforts will contribute to a better understanding of the ecology and history of oligochaetes in tropical ecosystems, to a higher esteem for the large diversity of these organisms, and to a systematic reorganization of the known diversity according to the very evolutionary processes that produced this diversity. This knowledge should promote efforts to protect habitats and should provide a more informative synthesis of our present knowledge of global biodiversity.

\section{ACKNOWLEDGEMENTS}

The continuing productivity scholarship from CNPq made it possible to concentrate efforts for gathering all the information available in the literature on oligochaete systematics. Jörg Römbke provided general key references during this research. Mark Wetzel exchanged experiences and provided suggestions on inventorying South American oligochaetes. Claudia Bérrio-Cárdenas provided references on Colombian oligochaetes. Luiz Ricardo Lopes de Simone provided access to the Gilberto Righi 
reference collection at Museu de Zoologia de São Paulo. George Gardner Brown invited me to give this talk at the Terceiro Encontro Latino-Americano de Ecologia e Taxonomia de Oligoquetas (ELAETAO3) in Curitiba, Brazil, December 3-6, 2007. I thank Carmen Alonso for providing the Spanish abstract of this paper.

\section{LITERATURE CITED}

Alroy, J. 2002. How many named species are valid? Proceedings of the National Academy of Sciences of the United States of America. 99(6):3706-3711.

Ayres, I. \& R. T. Guerra. 1981. Água como fator limitante na distribuição de minhocas (Annelida, Oligochaeta) da Amazonia central. Acta Amazonica. 11: 77-86.

Bittencourt, E. C. R. 1974. Algumas Enchytraeidae (Oligochaeta) de São Paulo. Revista Brasileira de Biologia. 34(3): 369-378.

Blakemore, R. J. 2002. Cosmopolitan earthworms - an eco-taxonomic guide to the peregrine species of the world. VermEcology, Kippax, Australia. [CD-ROM]

Brinkhurst, R. O. \& M. R. Marchese. 1989. Guide to the freshwater aquatic microdrile oligochaetes of South and Central America. Colección Clímax, Asociación de Ciencias Naturales de Litoral. 6: $1-179$.

Brown, G. G. \& S. W. James. 2007. Ecologia, biodiversidade e biogeografia das minhocas no Brasil. Pp. 297-382. In: G. G. Brown and C. Fragoso (Eds). Minhocas na América Latina: biodiversidade e ecologia. Embrapa Soja, Londrina, Paraná.

Brown, G. G., S. W. James, K. D. Sautter, A. Pasini, N. P. Benito, D. H. Nunes, E. F. Korasaki, C. Y. Santos, C. Y. Matsumura, P. T. Martins, A. Pavão, S. H. Silva, G. Garbelini \& E. Torres. 2004. Avaliação das populações de minhocas como bioindicadores ambientais no norte e leste do Estado do Paraná. Pp. 33-46. In: O. F. Saraiva (Ed.). Resultados de pesquisa da Embrapa soja 2003: Manejo de solos, plantas daninhas e agricultura de precisăo. Série Documentos, n. 253. Embrapa Soja, Londrina, Paraná.

Brown, G. G., S. W. James, A. Pasini, D. H. Nunes, N. P. Benito, P. T. Martins \& K. D. Sautter. 2006. Exotic, peregrine and invasive earthworms in Brazil: diversity, distribution and effects on soils and plants. Caribbean Journal of Science. 42: 339-358.

Christoffersen, M. L. 1976. Two species of Fridericia Mich., 1889 (Oligochaeta, Enchytraeidae) from Brazil. Boletim de Zoologia São Paulo. 1: 239-256.

Christoffersen, M. L. 1977. New species of Guaranidrilus Cernosv. (Enchytraeidae, Oligochaeta) from Serra do Mar, São Paulo, Brasil. Studies on Neotropical Fauna and Environment. 12: 187-206.

Christoffersen, M. L. 1979a. Some Enchytraeidae (Oligochaeta) from Serra do Mar, São Paulo, Brasil. Boletim de Zoologia São Paulo. 4: 39-52.

Christoffersen, M. L. 1979b. Achaeta neotropica Cernosvitov and A. iridescens sp. n. (Oligochaeta, Enchytraeidae) from Serra do Mar, São Paulo, Brasil. Zoologica Scripta. 8: 153-158.

Christoffersen, M. L. 2007a. Distribution and species diversity of Rhinodrilus Perrier, 1872 (Annelida, Clitellata, Lumbricina, Glossoscolecidae) in South America. Neodiversity. 2: 1-6.

Christoffersen, M. L. 2007b. Biodiversity and distribution of the Glossoscolex genus-group (Annelida, Clitellata, Lumbricina, Glossoscolecidae) in South America. Neotropical Biology and Conservation. 2: 155-160.

Christoffersen, M. L. 2007c. A catalogue of aquatic microdrile oligochaetes (Annelida: Clitellata) from South America. Acta Hydrobiologica Sinica. 31: 59-86.

Christoffersen, M. L. 2008a. A catalogue of the Ocnerodrilidae (Annelida, Oligochaeta) from South America. Italian Journal of Zoology. 75: 97-107. 
Christoffersen, M. L. 2008b. Species catalogue and phylogenetic relations of criodriloids and basal glossoscolecoids (Annelida Clitellata Lumbricina) from South America. Tropical Zoology. 21: 209-226.

Christoffersen, M. L. 2008c. A catalogue of the Pontoscolex genus-group other than Rhinodrilus from South America (Annelida, Clitellata, Lumbricina, Glossoscolecidae). Senckenbergiana Biologica. 88: 1-19.

Christoffersen, M. L. 2008d. Diversity and distribution of Aptodrilus, Glossodrilus, Onoreodrilus and Righiodrilus (Annelida, Clitellata, Lumbricina, Glossoscolecidae) in South America. Gaia Scientia. 2(2): 21-30.

Christoffersen, M. L. 2009. Species diversity and distributions of microdrile earthworms (Annelida, Clitellata, Enchytraeidae) from South America. Zootaxa. 2065: 51-68.

Decaens, T., J. J. Jiménez, C. Gioia, G. J. Measey \& P. Lavelle. 2006. The values of soil animals for conservation biology. European Journal of Soil Biology. 42: S23-S38.

De Deyn, G. B. \& W. H. Van Der Putten. 2005. Linking aboveground and belowground diversity. Trends in Ecology and Evolution. 20: 625-633.

Dozsa-Farkás, K. 1989. Neue Enchytraeiden-Arten (Oligochaeta) aus Ekuador. Acta Zoologica Hungarica. 35(3/4): 191-204.

Fragoso, C. \& G. G. Brown. 2007. Ecología y taxonomía de las lombrices de tierra en Latinoamérica: el primer Encuentro Latino-Americano de Ecología y Taxonomía de Oligoquetas (ELATAO1). Pp. 31-76. In: G. G. Brown and C. Fragoso (Eds). Minhocas na América Latina: biodiversidade e ecologia. Embrapa Soja, Londrina, Paraná.

Fragoso, C., G. G. Brown \& A. Feijoo. 2003. The influence of Gilberto Righi on tropical earthworm taxonomy: the value of a full-time taxonomist. Pedobiologia. 47: 400-404.

Gavrilov, K. 1979. Oligochaeta. Pp. 99-121. In: S. H. Hurlbert (Ed). Biota Acuatica de Sudamerica Austral. San Diego State University, San Diego, California.

Gavrilov, K. 1981. Oligochaeta. Pp. 170-190. In: S. H. Hurlbert, G. Rodriguez and N. D. Dos Santos (Eds). Aquatic biota of tropical South America. Being a compilation of taxonomic bibliographies for the fauna and flora of inland waters of the tropical portion of South America). Part 2. Anarthropoda. San Diego University, San Diego, California.

Hawkins, B. A. 2001. Ecology's oldest pattern? Trends in Ecology and Evolution. 16: 470.

Hortal, J., J. M. Lobo \& A. Jiménez-Valverde. 2007. Limitations of biodiversity databases: Case study on seed-plant diversity in Tenerife, Canary Islands. Conservation Biology. 21: 853-863.

James, S. W. \& G. G. Brown. 2006. Earthworm ecology and biodiversity. Pp. 56-116. In: F. M. S. Moreira, J. O. Siqueira and L. Brussaard (Eds). Soil biodiversity in Amazonian and other Brazilian ecosystems. Série Documentos, n. 253. CABI, Wellington, New Zealand.

Jamieson, B. G. M., S. Tillier, A. Tillier, J. L. Justine, E. Ling, S. James, K. McDonald \& A. F. Hugall. 2002. Phylogeny of the Megascolecidae and Crassiclitellata (Annelida, Oligochaeta): combined versus partitioned analysis using nuclear (28S) and mitochondrial (12S, 16S) rDNA. Zoosystema. 24(4): 707-734.

Judas, M. 1988. The species-area relationship of European Lumbricidae (Annelida, Oligochaeta). Oecologia. 76:579-587.

Kinberg, J. G. H. 1867. Annulata nova. Öfversigt af Kongliga Vetenskaps Academiens Förhandlingar. 23: 97-103.

Knäpper, C. F. U. 1972. Oligoquetas terrestres - uma moderna avaliação. Publicação do Instituto André Voisin Porto Alegre. 1: 11-19.

Knäpper, C. F. U. 1977. Ecological niches of P. diffringens (Baird, 1869) and E. lucens (Waga, 1857) at São Francisco de Paula. Estudos Leopensis. 42: 194-196. 
Lavelle, P., C. Lattaud, D. Trigo \& I. Barrois. 1995. Mutualism and biodiversity in soils. Plant and Soil. 170: 23-33.

Leuckart, F. S. 1835. Abbildung einer neuer gattung ringelwurm. Notizen Froriep. 46: 88.

Leuckart, F. S. 1836. Abbildung neuer Genus Ringelwurm. Isis (Oken):764.

Maraun, M., H. Schatz \& S. Scheu. 2007. Awesome or ordinary? Global diversity patterns of oribatid mites. Ecography. 30: 209-216.

Müller, F. 1857. Lumbricus corethrurus, Bürstenschwanz. Archiv für Naturgeschicht. 23: 113-116.

Procter, D. L. C. 1984. Towards a biogeography of free-living soil nematodes .1. Changing species richness, diversity and densities with changing latitude. Journal of Biogeography. 11: 103-117.

Righi, G. 1973. Sobre três espécies brasileiras de Enchytraeidae (Oligochaeta). Boletim de Zoologia e Biologia Marinha Nova Série. 30:469-482.

Righi, G. 1974a. Marionina pituca, sp.n. (Oligochaeta, Enchytraeidae) from Brazilian soil and its interstitial parasite Buetschliella marioninae, sp.n. (Ciliata, Astomata). Zoologischer Anzeiger. 192(5/6): 414-419.

Righi, G. 1974b. Notas sobre os Oligochaeta, Enchytraeidae do Brazil. Papéis Avulsos de Zoologia São Paulo. 28: 127-145.

Righi, G. 1975. Algumas Enchytraeidae (Oligochaeta) brasileiras. Ciência e Cultura. 27(2): 143-150.

Righi, G. 1978. Notas sobre os Oligochaeta da Amazônia. Acta Amazônica, 8(3): 485-488.

Righi, G. 1981a. Algumas Oligochaeta cavernicolas do Equador. Papéis Avulsos de Zoologia São Paulo. 34(22): 235-249.

Righi, G. 1981b. Notas sobre Enchytraeidae (Oligochaeta) brasileiras. Revista Brasileira de Biologia. 41(2): 427-430.

Righi, G. 1988. Dois novos microdrili, Oligochaeta, terrestres da Amazonia. Papéis Avulsos de Zoologia São Paulo. 36(27): 315-321.

Righi, G. 1990. Minhocas de Mato Grosso e de Rondônia. CNPq, Brasília.

Römbke, J. \& W. Hanagarth. 1994. The present faunistic knowledge on terrestrial Oligochaeta from Bolivia. Andrias. 13: 7-16.

Römbke, J., M. Meller \& M. Garcia. 1999. Earthworm densities in central Amazonian primary and secondary forests and a polyculture forestry plantation. Pedobiologia. 43: 518-522.

Schmelz, R. M. \& R. Collado. 2005. Achaeta becki sp. nov. (Oligochaeta: Enchytraeidae) from Amazonian forest soils. Zootaxa. 1084: 49-57.

Schmelz, R. M. \& J. Römbke. 2005. Three new species of Hemienchytraeus (Enchytraeidae, Oligochaeta) from Amazonian forest soil. Journal of Natural History. 39: 2967-2986.

Stork, N. E. \& M. J. Samways. 1995. Inventoring and monitoring. Pp. 453-544. In: V.H. Heywood and R.T. Watson (Eds). Global biodiversity assessment. Cambridge University Press, Cambridge.

Wheeler, Q. D. 1995. Systematics, the scientific basis for inventories of biodiversity. Biodiversity and Conservation Special Issue. 4: 476-489.

Willig, M. R. \& C. P. Bloch. 2006. Latitudinal gradients of species richness: a test of the geographic area hypothesis at two ecological scales. Oikos. 112: 163-173. 